\title{
HEAVY METAL TOLERANCE (Cr, Ag AND Hg) IN BACTERIA ISOLATED FROM SEWAGE
}

\author{
Agostinho A. de Lima e Silva ${ }^{1 *}$, Márcia A. Ribeiro de Carvalho ${ }^{1}$, Sérgio A. L de Souza ${ }^{1}$, Patrícia M. Teixeira Dias ${ }^{1}$, Renato \\ G. da Silva Filho ${ }^{1}$, Carmen S. de Meirelles Saramago ${ }^{1}$, Cleonice A. de Melo Bento ${ }^{1}$, Ernesto Hofer ${ }^{2}$ \\ ${ }^{1}$ Departamento de Microbiologia e Parasitologia, Universidade Federal do Estado do Rio de Janeiro, Rio de Janeiro, RJ, Brasil; \\ ${ }^{2}$ Laboratório de Zoonoses Bacterianas, Instituto Oswaldo Cruz, Rio de Janeiro, RJ, Brasil.
}

Submitted: September 25, 2011; Returned to authors for corrections: January 30, 2012; Approved: June 07, 2012.

\begin{abstract}
Samples of sewage from a university hospital and a chemistry technical school were analysed for the percentage of bacterial tolerance to chromium ( $\mathrm{Cr}$ ), silver (Ag) and mercury ( $\mathrm{Hg}$ ). Additionally, we investigated the effect of these metals on pigmentation and on some enzymatic activities of the metal tolerant strains isolated, as well as antimicrobial resistance in some metal tolerant Enterobacteriaceae strains. Tolerance to $\mathrm{Cr}$ was observed mainly in Gram positive bacteria while in the case of $\mathrm{Ag}$ and $\mathrm{Hg}$ the tolerant bacteria were predominately Gram negative. Hg was the metal for which the percentage of tolerance was significantly higher, especially in samples from the hospital sewage (4.1\%). Mercury also had the most discernible effect on color of the colonies. Considering the effect of metals on the respiratory enzymes, one strain of Ag-tolerant Bacillus sp. and one of Hg-tolerant P. aeruginosa were unable to produce oxidase in the presence of $\mathrm{Ag}$ and $\mathrm{Hg}$, respectively, while the expression of gelatinase was largely inhibited in various Gram negative strains (66\% by $\mathrm{Cr}$ ). Drug resistance in $\mathrm{Hg}$-tolerant Enterobacteriaceae strains isolated from the university hospital sewage was greater than $80 \%$, with prevalence of multiple resistance, while the Agtolerant strains from the same source showed about $34 \%$ of resistance, with the predominance of monoresistance. Our results showed that, despite the ability of metal tolerant strains to survive and grow in the presence of these elements, the interactions with these metals may result in metabolic or phisiological changes in this group of bacteria.
\end{abstract}

Key words: metal tolerance; sewage; pigment; enzymatic inhibition; antimicrobial resistance

\section{INTRODUCTION}

Heavy metals are a group of metals with density greater than $5 \mathrm{~g} / \mathrm{cm}^{3}$. They persist in nature and consequently tend to accumulate in food chains. Although relatively high levels of these elements occur in natural environment, their presence as a contaminant in ecosystems results mainly from anthropogenic activities (39).

Some heavy metals such as nickel, iron, copper and zinc are essential to metabolic reactions and are required as trace elements by the organisms. Others like mercury, silver and cadmium have no biological role and are harmful to the

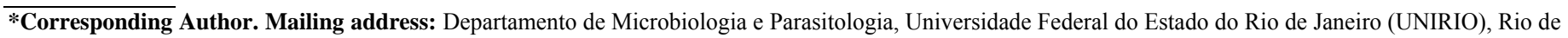
Janeiro, Brasil.; E-mail: agostinho.limaesilva@gmail.com 
organisms, even at very low concentrations (21).

Bacteria that demonstrate the capacity of surviving in toxic heavy metals concentrations have been isolated from different sources $(2,6,8,9,18,26,32)$.

Many bacteria have specific genetic mechanisms of resistance to toxic metals $(29,36)$. In the environment metals may select these resistant variants in a manner similar to the selection of antibiotic resistant strains. Indeed, it is relatively common the association of metal and antimicrobial resistance, since both resistance genes are frequently located on the same mobile genetic elements $(12,28)$. Consequently, it can be assumed that the selective pressure exerted by heavy metals contribute to the indirect co-selection of antibiotic resistance, particularly in environments contaminated with the two elements.

Concerning heavy metals, terms such as "resistance" and "tolerance" are arbitrary and they are often used as synonymous in literature. Gadd (15) suggested using the term "resistance" when it is possible to characterize a specific mechanism of bacterial detoxification for a metal. Therefore, the term tolerance seems more appropriate to refer to the ability of a bacterial strain to grow in the presence of high concentrations of a metal, in all cases in which the mechanism of this process has not been investigated.

The toxic effects of heavy metals on microorganisms are influenced by a multitude of factors such as $\mathrm{pH}$, concentration of chelating agents, speciation, and organic matter $(9,31,38)$. The presence of those elements in the environment can result in impacts on ecosystems, with alterations in the biomass, diversity of microbial communities and cycling of elements $(37,35)$.

Despite the large number of papers describing the action of heavy metals on microorganisms, there are few studies on the effects of toxic metals in the physiology of metal tolerant bacteria, in comparison to those about their inhibitory or deleterious effects on susceptible organisms $(17,40)$.

In our work we analyzed the presence of metal tolerance (chromium, silver and mercury) in bacteria from sewage, and some effects of heavy metals on microorganisms that are able to survive and grow in their presence. Bacterial pigmentation and enzymatic activities such as catalase, gelatin hydrolysis and nitrate reduction were the characteristics chosen to study these effects. We find it relevant to evaluate the possible interactions between these toxic elements and tolerant bacteria in regard to the physiological and metabolic alterations derived from this contact, because it can be important, for example, in situations such as in the utilization of metal tolerant microorganisms for bioremediation of contaminated environments. Additionally, metal tolerant Enterobacteriaceae strains were investigated for their resistance to antimicrobial drugs, intending to study the possible relationship between metal tolerance and antimicrobial resistance.

This study is part of a broader investigation which aims to obtain data about metal tolerant bacteria considering their potential use for bioremediation, as well as about the impact resulting from the interactions between metals and metal tolerant bacteria. Previously we have investigated the possible relationships between metal tolerance and the degradation of toxic aromatic compounds (25).

\section{MATERIALS AND METHODS}

\section{Samples}

Eleven samples of sewage from a chemistry school sewage (CSS) and nine from a university hospital sewage (UHS) were collected, with intervals of 1 or 2 months between each collection in the two institutions, both located in the northern region of Rio de Janeiro city. All samples consisted of $100 \mathrm{~mL}$ of sewage, collected in sterile bottles and transported in refrigeration to the laboratory.

\section{Isolation of chromium (Cr), silver (Ag) or mercury (Hg) tolerant bacteria}

After clarifying filtration using Whatman filter paper No. 1 , the sewage samples were serially diluted in phosphatebuffered saline. For the isolation and quantification of metal tolerant bacteria aliquots of $0.1 \mathrm{~mL}$ of undiluted sewage and 
$10^{-1}$ and $10^{-2}$ dilutions of each sample were inoculated on Nutrient Agar (Merck) containing $100 \mu \mathrm{g} / \mathrm{mL}$ of cycloheximide (Sigma) and one of the following metals: $\mathrm{K}_{2} \mathrm{Cr}_{2} \mathrm{O}_{7}$ (Vetec): 60, 110, 160, 210, 260, 310, $360 \mu \mathrm{g} / \mathrm{mL}$; $\mathrm{AgNO}_{3}$ (Sigma): 20, 25, 30, $35 \mu \mathrm{g} / \mathrm{mL} ; \mathrm{HgCl}_{2}$ (Hoechst): 60, $80,100,120 \mu \mathrm{g} / \mathrm{mL}$. The plates were incubated at $35^{\circ} \mathrm{C}$ for 24h. The metal concentrations were selected according to previous experiments (data not shown), which established the lower concentration of each metal that determined $\geq 95 \%$ reduction in the number of $\mathrm{cfu} / \mathrm{mL}$ when compared to the total number of $\mathrm{cfu} / \mathrm{mL}$ present in the sewage samples.

This arbitrary procedure was employed to define as metal tolerant those bacteria that were able to produce visible colonies within $24 \mathrm{~h}$ in the presence of the chosen metal concentrations. In order to determine the total number of bacteria present in each sewage sample, aliquots of $0.1 \mathrm{~mL}$ of $10^{-2}$ to $10^{-5}$ dilutions were plated on Nutrient Agar without metal. All plates were prepared in triplicate and incubated at $35^{\circ} \mathrm{C}$ for $24 \mathrm{~h}$. The metallic salts used were of analytical grade and its solutions sterilized by filtration with Millipore membranes with a $0.22 \mu \mathrm{m}$ pore size. Some reference strains of Gram positive and Gram negative species, with previously determined sensitivity or tolerance to metals at the tested concentrations, were used as controls of the metal activities: Escherichia coli ATCC 25922, Escherichia coli K12 PCG86, Pseudomonas aeruginosa ATCC 27853, Klebsiella pneumoniae ATCC 13883, Staphylococcus aureus ATCC 29213 and Enterococcus faecalis ATCC 29212. The number of colony forming units (cfu) observed in the plates were adjusted to $\mathrm{cfu} / \mathrm{mL}$ of sewage. $\mathrm{Cr}, \mathrm{Ag}$ and $\mathrm{Hg}$-tolerant $\mathrm{cfu} / \mathrm{mL}$ percentages were calculated by comparison with the results obtained in the medium without metal using the formula: number of $\mathrm{cfu} / \mathrm{mL}$ on Nutrient Agar supplemented with metal $\mathrm{x}$ $100 /$ number of cfu/mL on Nutrient Agar.

\section{Characterization of the isolates}

After counting, randomly chosen colonies from each plate were picked and inoculated in Nutrient Broth (Merck). After growth at $35^{\circ} \mathrm{C}$ for $18 \mathrm{~h}$ the strains were streaked onto Nutrient Agar without metal to ensure its purity and the Gram status was determined. Then, the strains were evaluated for the ability to grow on Nutrient Agar in the presence of the metal concentrations detected in the primary isolation.

The Gram-negative strains were plated onto MacConkey Agar (Merck) and inoculated in Glucose OxidationFermentation Medium. Some non-fermentative strains with interesting characteristics, such as tolerance to high concentrations of metals or pigment production in the presence of metals, were identified by conventional tests and the API 20 NE identification system (bioMérieux, Marcy l'Etoile, France). The fermentative bacteria were presumptively identified as members of the Enterobacteriaceae family by the oxidase and nitrate reduction tests. Conventional biochemical tests, with the aid of BBL E/NF kit, were used to identify a set of strains selected for antimicrobial susceptibility testing. The bacterial isolates were maintained on Nutrient Agar slants at $4^{\circ} \mathrm{C}$ for daily use, and stored in Brain Heart Infusion Broth (BHIMerck) with $20 \%$ glycerol at $-70^{\circ} \mathrm{C}$.

\section{Determination of the effect of heavy metals on bacterial} pigmentation

After storage of samples of metal tolerant colonies for further testing, the plates were wrapped in aluminum foil, packed in plastic bags, and reincubated at $35^{\circ} \mathrm{C}$. After 14 days the pigmented colonies were grown in Nutrient Broth at $35^{\circ} \mathrm{C}$ /24h and $10 \mu \mathrm{L}$ of cultures were placed on Nutrient Agar with different concentrations of the respective metal. The same media without metal was used as control. The plates were kept under the same incubation conditions described above. Strains that presented any degree of change on pigmentation or tone in comparison to the controls were subjected to further confirmatory tests, by repeating the procedure in triplicates for each strain. A strain of $P$. aeruginosa was chosen for an additional test of pigment production in media containing $\mathrm{Cr}$. After growth for 5 days in minimal medium (22) containing $\mathrm{K}_{2} \mathrm{Cr}_{2} \mathrm{O}_{7}$ in concentrations of 5, 10, 15 and $20 \mu \mathrm{g} / \mathrm{mL}$ and in 
minimal medium without the metal the tubes were centrifuged and the supernatants filtered with Millipore membranes with a $0.22 \mu \mathrm{m}$ pore size. Thereafter, the filtrates were mixed with chloroform $(1: 2 \mathrm{v} / \mathrm{v})$ and the aqueous phases analyzed in UVvisible spectrophotometer.

\section{Effect of metals on enzymatic activity}

The interference of metals on the expression of some enzymes in metal tolerant strains was evaluated indirectly by the catalase, oxidase, gelatin hydrolysis and nitrate reduction tests. For each test, 30 randomily chosen strains with positive results in the absence of the metals were analyzed. In the oxidase tests 25 strains of Pseudomonas spp. and 5 of Bacillus spp. were analyzed while in the other tests 15 strains of Pseudomonas spp. and 15 of Enterobacteriaceae were employed. P. aeruginosa ATCC 27853 and E. coli ATCC 25922 were used as controls in these biochemical tests. The metal concentrations used in these tests were those that did not show changes in the growth of the strains in comparison to the media without metal (control). The culture media used and the concentrations of metals were as follows: catalase and oxidase tests - Nutrient Agar with $\mathrm{K}_{2} \mathrm{Cr}_{2} \mathrm{O}_{7}(60,110,160 \mu \mathrm{g} / \mathrm{mL})$; $\mathrm{AgNO}_{3}(15,20,30 \mu \mathrm{g} / \mathrm{mL}) ; \mathrm{HgCl}_{2}(40,60,80 \mu \mathrm{g} / \mathrm{mL})$; nitrate reduction tests - Nitrate Broth (BBL) with $\mathrm{K}_{2} \mathrm{Cr}_{2} \mathrm{O}_{7}(5,10,50$ $\mu \mathrm{g} / \mathrm{mL}) ; \mathrm{AgNO}_{3}(1,5,10 \mu \mathrm{g} / \mathrm{mL}) ; \mathrm{HgCl}_{2}(10,20,30 \mu \mathrm{g} / \mathrm{mL})$; gelatin hydrolysis tests - Nutrient Gelatin (Merck) with $\mathrm{K}_{2} \mathrm{Cr}_{2} \mathrm{O}_{7}(100,120,140 \mu \mathrm{g} / \mathrm{mL}) ; \operatorname{AgNO}_{3}(15,20,30 \mu \mathrm{g} / \mathrm{mL})$; $\mathrm{HgCl}_{2}(20,40,80 \mu \mathrm{g} / \mathrm{mL})$. All tests were made in triplicates and repeated at least three times. The cytocrome oxidase test was not employed in the strains grown in the presence of $\mathrm{K}_{2} \mathrm{Cr}_{2} \mathrm{O}_{7}$ because of the oxidative effect of this metal on the reagent used in the test (tetramethyl-p-phenylenediamine dihydrochloride). The conditions of inoculation, incubation and reading of the tests were in accordance to the methods of MacFaddin (27).

\section{Antimicrobial susceptibility testing}

Enterobacteriaceae strains that presented tolerance to
$\mathrm{HgCl}_{2}$ in concentrations $\geq 80 \mu \mathrm{g} / \mathrm{mL}$ and to $\mathrm{AgNO}_{3} \geq 30$ $\mu \mathrm{g} / \mathrm{mL}$ were identified and tested for susceptibility to antimicrobial agents by the disk diffusion method $(3,30)$ in Mueller-Hinton agar (Merck). The antimicrobial agents (Cecon) used were: amikacin $(30 \mu \mathrm{g})$, chloramphenicol $(30 \mu \mathrm{g})$, gentamicin $(10 \mu \mathrm{g})$, sulfamethoxazole-trimethoprim $(25 \mu \mathrm{g})$, tetracycline $(30 \mu \mathrm{g})$, norfloxacin $(10 \mu \mathrm{g})$, ciprofloxacin $(5 \mu \mathrm{g})$, tobramycin $(10 \mu \mathrm{g})$ and cefotaxime $(30 \mu \mathrm{g})$. Reference strains such as E. coli ATCC 25922, S. aureus ATCC 25923 and $P$. aeruginosa ATCC 27853 were used as controls. The distribution of $\mathrm{Ag}$ and $\mathrm{Hg}$-tolerant Enterobacteriaceae strains tested for susceptibility to antimicrobial agents was as follows: UHS - 35 Ag-tolerant strains ( $K$. pneumoniae being the predominant specie [10 strains]) and $36 \mathrm{Hg}$-tolerant strains (predominantly species of the genus Enterobacter [15 strains]); CSS - 32 Ag-tolerant strains (predominantly E. cloacae [21 strains]) and $33 \mathrm{Hg}$-tolerant strains (predominance of $K$. pneumoniae [13 strains]).

\section{Statistical analysis}

The statistical analysis of the mean values of $\mathrm{cfu} / \mathrm{mL}$ of metal tolerant bacteria from CSS and UHS was performed by a comparison of proportions by the Student's $t$ test, with confidence levels of $5 \%$ being considered significant.

\section{RESULTS AND DISCUSSION}

Factors such as the culture media employed, growth conditions, and incubation period, besides the various possible forms and concentrations of metals used in the tests of tolerance may difficult their standardization and influence the in vitro toxicity of the metals $(9,38)$. Due to these facts there are no universally accepted metal concentrations to define bacterial tolerance or resistance.

In this context we proposed to use in this study concentrations of each metal that determined $\geq 95 \%$ reduction in the number of $\mathrm{cfu} / \mathrm{mL}$ when compared to the total population present in the sewage sample. Using this pattern of metal concentrations allowed us to detect subpopulations of bacteria 
that presented a differential behavior of metal tolerance in comparison to the general population present in the sewage, even though we can presume that this procedure may underestimate the real percentage of metal tolerant bacteria.

Table 1 shows the average percentage of metal tolerant bacteria in the lowest concentrations of the metals. In the highest concentration of each metal, colonies were still detected, but with rates of $\mathrm{cfu} / \mathrm{mL}$ lower than $0.1 \%$ (data not shown). The average rates of $\mathrm{cfu} / \mathrm{mL}$ obtained in media containing $\mathrm{Cr}$ and $\mathrm{Ag}$ were very low in the samples from both institutions, reflecting, perhaps, the absence of selective pressure in these environments.

Table 1. Number of bacteria and prevalence on bacterial types obtained in the lowest concentrations of heavy metals

\begin{tabular}{|c|c|c|c|c|c|c|}
\hline \multirow{3}{*}{ Nutrient agar with: } & \multicolumn{3}{|c|}{ CSS } & \multicolumn{3}{|c|}{ UHS } \\
\hline & \multirow{2}{*}{$\begin{array}{c}\mathrm{cfu} / \mathrm{mL} \\
5.3 \times 10^{5 *} \\
(\%)\end{array}$} & \multicolumn{2}{|c|}{$\%$ Bacteria } & \multirow{2}{*}{$\begin{array}{c}\mathrm{cfu} / \mathrm{mL} \\
4.2 \times 10^{5 *} \\
(\%)\end{array}$} & \multicolumn{2}{|c|}{$\%$ Bacteria } \\
\hline & & $\mathrm{G}+$ & G - & & $\mathrm{G}^{+}$ & G - \\
\hline $\begin{array}{c}\mathrm{K}_{2} \mathrm{Cr}_{2} \mathrm{O}_{7} \\
{[60]}\end{array}$ & $\begin{array}{c}5.3 \times 10^{3} \\
(1.0)\end{array}$ & $71.5^{* *}$ & 28.5 & $\begin{array}{c}5.5 \times 10^{3} \\
(1.3)\end{array}$ & $68.4^{* *}$ & 31.6 \\
\hline $\begin{array}{c}\mathrm{AgNO}_{3} \\
{[20]}\end{array}$ & $\begin{array}{c}2.1 \times 10^{3} \\
(0.4)\end{array}$ & 9.3 & $90.7^{* * *}$ & $\begin{array}{c}2.1 \times 10^{3} \\
(0.5)\end{array}$ & 48.4 & $51.6^{* * *}$ \\
\hline $\begin{array}{c}\mathrm{HgCl}_{2} \\
{[60]}\end{array}$ & $\begin{array}{c}1.1 \times 10^{4} \\
(2.0)\end{array}$ & 10.7 & 89.3 & $\begin{array}{c}1.7 \times 10^{4} \\
(4.1)\end{array}$ & 5.2 & 94.8 \\
\hline
\end{tabular}

Abbreviations: CSS, Chemistry school; UHS, University hospital; G+, Gram positive; G-, Gram negative.

[ ]: $\mu \mathrm{g} / \mathrm{mL}$.

" mean total count of $\mathrm{cfu} / \mathrm{mL}$ obtained in media without metal.

${ }^{* *} 100 \%$ in the concentration of $310 \mu \mathrm{g} / \mathrm{mL}$ of the metal.

${ }^{* * *} 100 \%$ in the concentration of $35 \mu \mathrm{g} / \mathrm{mL}$ of the metal.

The percentage of Hg-tolerant strains from both sources were significantly higher (Students $t$ test, $\alpha=5 \%$ ) when compared to the other metals tested, especially in samples from the hospital sewage (UHS), in which the average rate of $\mathrm{cfu} / \mathrm{mL}$ in the presence of $60 \mu \mathrm{g} / \mathrm{mL}$ of $\mathrm{HgCl}_{2}$ was about $4 \%$. This result is interesting, in view of the fact that the use of $\mathrm{Hg}$ as a component of antiseptics was prohibited in Brazil since $2001(5)$.

Considering that tolerance to $\mathrm{Hg}$ is probably due to $\mathrm{Hg}^{\mathrm{R}}$ genes which are often associated with genes that confer resistance to antimicrobial drugs (12), it is possible to admit that the intense use of these drugs in the hospital environment may contribute to the maintenance of genes $\mathrm{Hg}^{\mathrm{R}}$ in the bacterial population of this area.

In this study it was observed a predominance of Grampositive bacteria among the Cr-tolerant strains isolated from both sewage sources in all studied concentrations of the metal (Table 1). In the concentration of $310 \mu \mathrm{g} / \mathrm{mL}$ of the metal the prevalence was $100 \%$ (data not shown). These results are in accordance with those of Basu et al (2) which characterized the strains with highest tolerance to chromate as Gram-positive bacteria.

Analysing the bacterial groups isolated in the highest concentrations of $\mathrm{Cr}$, the Gram positive were predominantly non-sporulated or sporulated rods and staphylococci, while the Gram negative were represented exclusively by nonfermentative microorganisms, most of them identified as Pseudomonas spp. (Table 2).

In the case of the sewage samples collected from the chemistry school (CSS), almost $90 \%$ of the strains that were able to grow in the presence of $20 \mu \mathrm{g} / \mathrm{mL}$ of $\mathrm{AgNO}_{3}$ were identified as Gram negative, in contrast to those obtained from the hospital (UHS), in which the percentages of Gram positive and Gram negative bacteria were similar (Table 1). Nevertheless, in the presence of $35 \mu \mathrm{g} / \mathrm{mL}$ of this metal, $100 \%$ of the bacteria were Gram negative in both sewage sources. It is important to mention that in the case of Gram positive bacteria no resistance determinant to $\mathrm{Ag}$ has been characterized 
(33).

The Gram-negative microorganisms isolated in the highest concentrations of $\mathrm{Ag}$ in both sewage sources were predominantly glucose fermentatives bacteria, which belonged to the Enterobacteriaceae family (Table 2).

Gram negative bacteria were also predominant in the media containing $\mathrm{HgCl}_{2}$ (Table 1). The results obtained in this study, concerning $\mathrm{Ag}$ and $\mathrm{Hg}$, are in accordance with other studies that have demonstrated that Gram-negative bacteria tend to be more tolerant to heavy metals than Gram positive (9, 10, 20). Unlike what was observed with $\mathrm{Ag}$, glucose non- fermentative Gram negative bacteria were predominant in the highest concentrations of $\mathrm{Hg}$, with a significant presence of Pseudomonas spp. (Table 2).

The effect of heavy metals in the results of some biochemical tests and on bacterial pigmentation was investigated, in order to determine if the metals could induce modifications in the physiology of tolerant bacteria, without impairing their growth. The biochemical tests analyzed were catalase, oxidase and nitrate reduction, which indicate enzymatic activities involved in respiratory processes and gelatin hydrolysis, which indicates nutritional activity.

Table 2. Distribution and identification of bacterial types in the highest concentrations of heavy metals

\begin{tabular}{|c|c|c|c|c|}
\hline \multirow[t]{2}{*}{ Metal } & \multirow[t]{2}{*}{ Sewage } & \multicolumn{3}{|r|}{ Bacterial isolates } \\
\hline & & G+ ${ }^{\mathrm{A}}$, rod-shaped & $\mathrm{G}+{ }^{\mathrm{A}}$, cocci & G- ${ }^{\mathrm{B}}$, rod-shaped \\
\hline $\begin{array}{l}\mathrm{K}_{2} \mathrm{Cr}_{2} \mathrm{O}_{7} \\
{[260-310]}\end{array}$ & UHS & $\begin{array}{l}\text { Non-sporulated } \\
(36), \text { sporulated }(25), \\
\text { actinomycetes }(7)\end{array}$ & $\begin{array}{l}\text { Staphylococci }{ }^{\mathrm{C}} \\
(30) \text {, other }(11)\end{array}$ & $\begin{array}{l}\mathrm{NF}^{\mathrm{D}^{*}}: \text { Pseudomonas }\{P . \text { aeruginosa } \\
(5), P \text {. putida (5), P. fluorescens (3) }\} \text {, Alcaligenes spp. (2), } \\
\text { Stenotrophomonas maltophilia (2), unidentified (5) }\end{array}$ \\
\hline $\begin{array}{l}\mathrm{AgNO}_{3} \\
{[25-35]}\end{array}$ & UHS & $\begin{array}{l}{ }^{* *} \text { Coryneform organisms } \\
(10),{ }^{* *} \text { sporulated }(6)\end{array}$ & (3) & $\begin{array}{l}\mathrm{NF}^{\mathrm{D}}: \text { Pseudomonas }\{P . \text { stutzeri (3), P. aeruginosa }(3)\}, S . \\
\text { maltophilia (3), C. indologenes (3), Acinetobacter spp. }(2) \\
\mathrm{F}^{\mathrm{E}}: \text { Klebsiella }\{\text { K. pneumoniae }(10), \text { K. oxytoca }(1)\}, \text { Enterobacter } \\
\{\text { E. agglomerans }(6), \text { E. cloacae complex }(5)\}, \text { Citrobacter }\{C . \\
\text { freundii (4), C. youngae (3), C. braakii (1), C. species } 10(1)\}, \\
\text { Serratia marcescens (4), Proteus vulgaris (2), Kluyvera } \\
\text { cryocrescens }(1)\end{array}$ \\
\hline \multirow{2}{*}{$\begin{array}{l}\mathrm{HgCl}_{2} \\
{[\geq 80]}\end{array}$} & CSS & $\begin{array}{l}\text { Non-sporulated (25), } \\
\text { sporulated (5) }\end{array}$ & $\begin{array}{l}\text { Staphylococci }{ }^{\mathrm{C}} \\
(6), \text { other }(8)\end{array}$ & $\begin{array}{l}\mathrm{NF}^{\mathrm{D}}: \text { Pseudomonas }\{P . \text { fluorescens }(24), \text { P. putida }(17), P . \\
\text { aeruginosa }(14), \text { Pseudomonas spp. }(12)\}, \text { B. cepacia }(8), \\
\text { Alcaligenes spp. (6), Sphyngomonas paucimobilis (2), Ralstonia } \\
\text { pickettii (1) } \\
\mathrm{F}^{\mathrm{E}}: \text { K. pneumoniae (13), E.cloacae complex (10), Serratia }\{S . \\
\text { liquefaciens group (4), S. rubidaea }(2)\}, \text { Citrobacter spp. }(2) ; \\
\text { Escherichia coli (1), Aeromonas caviae (2) }\end{array}$ \\
\hline & UHS & $\begin{array}{l}\text { Non-sporulated (32), } \\
\text { sporulated (10) }\end{array}$ & $\begin{array}{l}\text { Staphylococci }{ }^{\mathrm{C}} \\
(7), \text { other }(5)\end{array}$ & $\begin{array}{l}\mathrm{NF}^{\mathrm{D}}: \text { Pseudomonas }\{P . \text { aeruginosa }(22), P \text {. fluorescens }(20), P . \\
\text { putida }(14), \text { Pseudomonas spp. }(14)\}, \text { B. cepacia }(6), \text { Alcaligenes } \\
\text { spp. (4), S. paucimobilis } \\
\text { (3), Brevundimonas vesiculares (1), Chryseobacterium } \\
\text { meningosepticum (1) } \\
\mathrm{F}^{\mathrm{E}} \text { : Enterobacter }\{\text { E. cloacae complex (13), E.agglomerans }(3)\}, \\
\text { K. pneumoniae (9); Serratia spp. (6), Citrobacter }\{\text { C. freundii (3), } \\
\text { C. youngae (2)\} }\end{array}$ \\
\hline
\end{tabular}

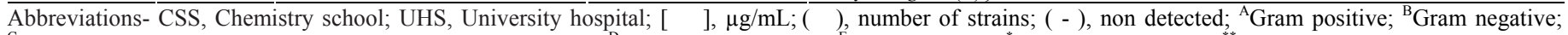
${ }^{\mathrm{C}}$ grapelike clusters, catalase positive and glucose fermentative; ${ }^{\mathrm{D}} \mathrm{NF}$, non-fermentative; ${ }^{\mathrm{E}} \mathrm{F}$ : fermentative; ${ }^{*}$ absent at $310 \mu \mathrm{g} / \mathrm{mL} ;{ }^{* *}$ absent at $35 \mu \mathrm{g} / \mathrm{mL}$. 
All the metals tested expressively interfered with gelatin hydrolysis in metal tolerant strains that previously were gelatinase positive (Table 3). Gelatin hydrolysis is a test used to determine the ability of microorganisms to produce extracellular proteases that degrade this substrate, a connective tissue protein that results from the structural and chemical degradation of collagen. Some bacteria and eucaryote organisms produce metalloproteases that are able to degrade not only gelatin but also native collagen, and for this reason they are called collagenases. Bacterial collagenases may be severely inhibited by metals like $\mathrm{Cr}^{3+}$ and this characteristic can be relevant, for example, to the stabilization of collagen in the industrial treatment of leather (16).

Table 3. Number of Gram negative strains that presented inhibition of gelatin hydrolysis in the presence of different metal concentrations $^{*}$

\begin{tabular}{|c|c|c|c|c|c|}
\hline $\begin{array}{l}\mathbf{K}_{2} \mathbf{C r}_{2} \mathbf{O}_{7} \\
(\mu \mathrm{g} / \mathrm{mL})\end{array}$ & $\begin{array}{c}\text { Inhibition of gelatin } \\
\text { hydrolysis } \\
\mathbf{N}^{\mathbf{0}}(\%) \\
\end{array}$ & $\begin{array}{c}\mathrm{AgNO}_{3} \\
(\mu \mathrm{g} / \mathrm{mL})\end{array}$ & $\begin{array}{c}\text { Inhibition of gelatin } \\
\text { hydrolysis } \\
\mathbf{N}^{\circ} /(\%) \\
\end{array}$ & $\begin{array}{c}\mathbf{H g C l}_{2} \\
(\mu \mathrm{g} / \mathrm{mL})\end{array}$ & $\begin{array}{c}\text { Inhibition of gelatin } \\
\text { hydrolysis } \\
\mathbf{N}^{0} /(\%) \\
\end{array}$ \\
\hline $100 / 120 / 140$ & $13(43.3)$ & $15 / 20 / 30$ & $9(30.0)$ & $20 / 40 / 80$ & $3(10.0)$ \\
\hline $120 / 140$ & $2(6.6)$ & $20 / 30$ & $4(13,3)$ & $40 / 80$ & 0 \\
\hline 140 & $5(16.6)$ & 30 & $3(10.0)$ & 80 & $3(10.0)$ \\
\hline Total & $20(66.6)$ & Total & $16(53.3)$ & Total & $6(20.0)$ \\
\hline
\end{tabular}

* All strains tested were positive for gelatin hydrolysis in the absence of metals

Bacterial gelatinases in the presence of metallic elements may be affected in different manners. Pires-Bouças et al (34), studying the influence of divalent cations on the gelatinolytic activity of Enterococcus faecalis, observed that $\mathrm{Ca}^{2+}$ and $\mathrm{Zn}^{2+}$ caused a reduction in gelatinase production, while other common divalent cations $\left(\mathrm{Fe}^{2+}\right.$ and $\left.\mathrm{Cu}^{2+}\right)$ inhibited it or had no effect $\left(\mathrm{Mg}^{2+}\right)$. On the other hand, considering that the authors did not work with metal tolerant strains, it is important to emphasize that, in the case of some of the cations tested, gelatinase inhibition may be related to the deleterious effect of these agents on the bacterial cell.

Kanayama and Sakai (23) observed that metals like Al, Cu and $\mathrm{Fe}$ in concentrations higher than $10 \mathrm{mM}$ completely inhibited the activity of purified gelatinase, obtained from Microbacterium liquefaciens isolated from the soil of an industrial complex of gelatin production, while $\mathrm{Ca}, \mathrm{Ni}, \mathrm{Mn}$ and $\mathrm{Mg}$ slightly enhanced this enzymatic activity.

Since many gelatinases belong to the group of metalloproteases, one possible explanation for the inhibitory effect of heavy metals on these enzymes is that they may act by displacing native metals from their normal binding sites (21).

The production of catalase was not affected by the presence of heavy metals, suggesting that in tolerant bacteria this enzyme is well protected and keeps its functional activity in the presence of metals. This protection is important because in the absence of this enzyme hydrogen peroxide accumulates and may become lethal to bacteria.

The expression of oxidase was not affected by the presence of metals in almost all tolerant strains studied, except for one strain of Ag-tolerant Bacillus sp. that was unable to produce the enzyme in the presence of 15 and $30 \mu \mathrm{g} / \mathrm{mL}$ of $\mathrm{AgNO}_{3}$, and one strain of Hg-tolerant P. aeruginosa that was unable to produce the enzyme in the presence of 40 and 80 $\mu \mathrm{g} / \mathrm{mL}$ of $\mathrm{HgCl}_{2}$.

The oxidase test uses certain reagent dyes, such as tetramethyl-p-phenylenediamine dihydrochloride, that substitute the oxygen as artificial electron acceptors, and is positive when bacterial cells contain cytochrome $c$. The negative results induced by $\mathrm{Ag}$ and $\mathrm{Hg}$ in strains of Bacillus sp. and $P$. aeruginosa formerly positive indicate that even though these strains are metal tolerant, the presence of these elements may cause inactivation of some components of the respiratory chain that determine the oxidation of the reagent that is used as final electron acceptor in this test. So, in order to be able to 
grow in the presence of the metal, these strains might have an alternative component, additional to cytochrome $c$, in the final portion of the respiratory chain, which is not inactivated by the metal and does not determine the oxidation of the reagent used in the test.

In relation to the nitrate reduction test, no remarkable changes were observed in the behavior of nitrate-reducing metal tolerant bacteria, in the presence of metal. The only exception was a strain of $P$. aeruginosa that in concentrations of 5 and $10 \mu \mathrm{g} / \mathrm{mL}$ of $\mathrm{K}_{2} \mathrm{Cr}_{2} \mathrm{O}_{7}$ reduced nitrate to products other than nitrite, as presumed by the absence of red color in the test, even after the addition of zinc powder. But, in the presence of $50 \mu \mathrm{g} / \mathrm{mL}$ of this metal, the production of nitrite was detected by the production of red color, indicating that, in this concentration, the metal impaired the reduction of nitrate to products such as ammonia, molecular nitrogen, nitric oxide, nitrous oxide and hydroxylamine.

Given the results of the biochemical tests used in this study to evaluate the effect of metals on some enzymatic activities of tolerant strains it is reasonable to hypothesize that some enzymes can be affected by the presence of metals, without any impairment in bacterial growth. So we may suppose that the presence of metallic pollutants in the environment, besides causing death or inhibition of susceptible populations, can also inhibit the activity of some enzymes in the metal tolerant populations, eliciting important changes in the degradation of substrates and in the cycling of chemical elements.

The presence of metals favored changes in color or hue of some metal tolerant strains growing on solid medium. A strain of $S$. aureus showed an increase in yellow pigmentation in the presence of 40 to $100 \mu \mathrm{g} / \mathrm{mL}$ of $\mathrm{K}_{2} \mathrm{Cr}_{2} \mathrm{O}_{7}$, which was suppressed when the concentration increased to $160 \mu \mathrm{g} / \mathrm{mL}$ (Figure 1). This strain was able to grow in the presence of up to $260 \mu \mathrm{g} / \mathrm{mL}$ of the metal.

One strain of $P$. aeruginosa, showing a slightly green color in media without metal, started to develop a dark green color in the presence of $40 \mu \mathrm{g} / \mathrm{mL}$ of $\mathrm{K}_{2} \mathrm{Cr}_{2} \mathrm{O}_{7}$ which achieved its higher intensity in $160 \mu \mathrm{g} / \mathrm{mL}$, which was also the higher concentration in which bacterial growth was observed. Spectrophotometric tests analyzing filtrates from this strain grown in minimal medium with and without $\mathrm{Cr}$ confirmed the enhancing effect of the metal in the production of yellow-green pigment, with maximum absorbance in the range of 400-410 nm. Nevertheless, we could not establish a linear relationship between the intensification of pigment production and the different concentrations of $\mathrm{Cr}$ tested.

With regard to $\mathrm{HgCl}_{2}$, one strain of Sphingomonas paucimobilis and one strain of Brevundimonas vesicularis evolved from yellow to dark brown at 60 to $100 \mu \mathrm{g} / \mathrm{mL}$ while an unidentified Gram-negative strain with a slight yellowish pigmentation darkened when exposed to 80 and $100 \mu \mathrm{g} / \mathrm{mL}$ of the same metal. Also, a Gram-positive, rod-shaped, nonsporulated, ivory-pigmented bacterial strain developed increasing dark color and metallic diffuse halo in the presence of 80 to $120 \mu \mathrm{g} / \mathrm{mL}$ of $\mathrm{HgCl}_{2}$ (Figure 1).

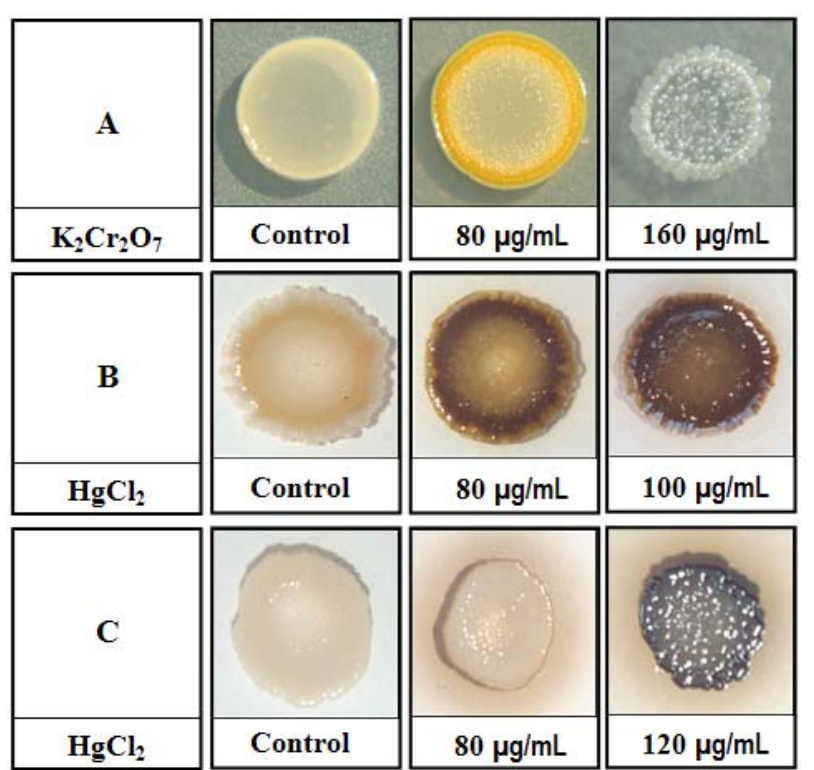

Figure 1. Effect of heavy metals on the pigmentation of different bacterial strains. A: S. aureus strain grown in media without metal (control) and with $\mathrm{K}_{2} \mathrm{Cr}_{2} \mathrm{O}_{7}$. B: Gram negative rod shaped strain grown in media without metal (control) and with $\mathrm{HgCl}_{2}$. C: Gram positive rod shaped strain grown in media without metal (control) and with $\mathrm{HgCl}_{2}$ 
The presence of $\mathrm{AgNO}_{3}$ affected only a strain of Chryseobacterium indologenes, which acquired a black hue when exposed to concentrations of 20 to $25 \mu \mathrm{g} / \mathrm{mL}$ of the metal.

Considering $\mathrm{Ag}$ and $\mathrm{Hg}$, the concentrations of the metals which determined the limit of bacterial growth were the same as those in which changes in the colony colors were still noted, suggesting that these changes may be associated to the metal tolerance.

Bacterial pigments provide essential protection against photooxidative damage in photosynthetic and nonphotosynthetic organisms (1). When present in low levels, toxic metals may inhibit bacterial pigmentation $(14,19)$. In some cases, the capacity to produce pigment may be directly associated to metal tolerance. Fugimore et al (13) observed that a red pigment-deficient white mutant of Pseudomonas K-62 showed greater sensitivity to $\mathrm{Hg}^{2+}$ than the parent wild-type reddish strain. In our study, for the strain of $S$. aureus that enhanced the pigment production in the presence of $\mathrm{Cr}$ this association was not observed, since this strain stopped to produce pigment in the presence of $160 \mu \mathrm{g} / \mathrm{mL}$ of this metal, even though it was able to grow until to the concentration of $260 \mu \mathrm{g} / \mathrm{mL}$.

In contrast, for a strain of $P$. aeruginosa isolated in the present study, this association may be implied, since the degree of pigment production showed a direct relationship with the presence of $\mathrm{Cr}$, achieving its higher intensity in the concentration of the metal which was also the limit for the growth of the bacteria.

With regard to $\mathrm{Ag}$ and $\mathrm{Hg}$, the changes observed in the colony colors are perhaps due to chemical modification of metals when interacting with the bacteria, and not to the induction of real pigmentation. Haefeli et al (18) observed that colonies of $P$. stutzeri $\mathrm{Ag}^{\mathrm{R}}$ grown in medium with the metal and $\mathrm{NaCl}$ became dark after exposure to light, a consequence of the formation of silver chloride, which was photo-converted later to metallic silver. Since this study was conducted with the plates shielded from light, it is possible that the darkening observed in the colonies was a result of the ability of strains to reduce $\mathrm{Ag}^{+}$to $\mathrm{Ag}^{\circ}$, or to precipitate the metal in its sulfide form. Similarly, the metallic brown halo observed around the growth of the Gram positive strain when exposed to $\mathrm{Hg}$ may be the result of a reaction of $\mathrm{Hg}$ with some substance released by the bacteria in the environment, or bioaccumulation of the metal, followed by its excretion into the environment in a chemically reduced form.

In order to investigate the relationship between metal tolerance and antimicrobial resistance we identified 67 strains of Ag-tolerant and 69 of Hg-tolerant Enterobacteriaceae isolated in media with high concentrations of these metals. $K$. pneumoniae and Enterobacter spp. were the predominant bacteria detected.

Ag-tolerant strains isolated from the UHS showed higher overall rate of resistance to antimicrobial agents than strains from the CSS, which was an expected result in the case of hospital strains (Table 4). However, it is important to emphasize that most Ag-tolerant Enterobacteriaceae strains isolated from the hospital sewage showed susceptibility to the drugs tested, as well as predominance of mono-resistance profile. This result is in accordance with literature information since the occurrence of a significant association between the phenomenon of tolerance to $\mathrm{Ag}$ and antibiotic resistance has not been reported $(8,22)$.

It is important to consider that, differently from $\mathrm{Hg}$, there are not many reports of $\mathrm{Ag}$ tolerance, since this characteristic is considered unstable and difficult to maintain and transfer (7, 33). Besides, we must consider that, in some cases, tolerance to this metal is not a true resistance derived from genetic expression, but a result of the production of capsular polysaccharides, which can combine with metals and protect the bacteria from toxicity (4).

Concerning antimicrobial resistance in Ag-tolerant strains, the main difference between the samples obtained from the two institutions was the multi-resistance, which was greater in those isolated from the hospital sewage. In contrast, the $\mathrm{Hg}$ tolerant strains isolated from the UHS had overall rate of 
antibiotic resistance greater than $85 \%$, with a predominance of multi-resistance. In the Hg-tolerant strains from the CSS the overall rate of resistance was $33.6 \%$, a value similar to that of Ag-tolerant strains from the hospital sewage. These results are consistent with reports on the frequent association between tolerance to $\mathrm{Hg}$ and antimicrobial resistance found in strains isolated from different sources $(22,24,26,28,41)$. Probably this is due to the fact that genes that code for antibiotic resistance and genes that code for mercury resistance are often carried on the same plasmids or other mobile genetic elements $(41,42)$, favouring the occurrence of co-selective processes in the presence of this metal or of antimicrobial drugs.

Table 4. Distribution of antimicrobial resistance in strains of metal tolerant Enterobacteriaceae

\begin{tabular}{ccccc}
\hline \multirow{2}{*}{$\begin{array}{c}\text { Antimicrobial } \\
\text { agent }\end{array}$} & \multicolumn{2}{c}{$\begin{array}{c}\text { Ag-tolerant strains } \\
\text { Source }\end{array}$} & \multicolumn{2}{c}{ Hg-tolerant strains } \\
Source
\end{tabular}

Abbreviations: AM, amikacin; C, chloramphenicol; TOB, tobramycin; GEN, gentamicin; CIP, ciprofloxacin; TET, tetracycline; NFX, norfloxacin; SXT, sulfamethoxazole-trimethoprim; CEF, cefotaxime. UHS, University Hospital Sewage; CSS, Chemistry School Sewage.

[ ], Number of strains tested

( ), Percentage of resistance

$\mathrm{Ab}^{\mathrm{R}}$, Antimicrobial resistance

Analysing resistance to each antimicrobial agent in separate, the strains of Hg-tolerant Enterobacteriaceae isolated from the CSS were basically resistant to trimethoprimsulfamethoxazole and tetracycline. These results are consistent with those obtained by Ferreira da Silva et al (11), who found a positive correlation between resistance to these drugs and $\mathrm{Hg}$ tolerance in Enterobacteriaceae isolated from wastewater treatment plant. The use of these drugs for decades probably explains the presence of resistant strains, including those from non-clinical origin. In the case of Ag-tolerant strains isolated from UHS, exhibiting resistance to one or more antimicrobial drugs, none of them was resistant to quinolones. Among the Hg-tolerant strains from the same institution, resistance to these drugs was present but in the lowest percentages among all drugs tested.

In conclusion, we observed that the concentrations of $\mathrm{Cr}$ employed in this study selected predominantly Gram positive bacteria, with exclusive presence of these bacteria in the highest concentration of the metal. In contrast, $\mathrm{Hg}$ and $\mathrm{Ag}$ selected mainly Gram negative bacteria. These data indicate that, depending on the pollutant metal, structural characteristics of the cell wall may be one of the aspects determining the survival of microorganisms in contaminated environments.

$\mathrm{Hg}$ tolerance was significantly higher in strains from hospital sewage and, in contrast to $\mathrm{Ag}$ tolerance, this characteristic was closely related to antimicrobial resistance and multi-resistance in the Enterobacteriaceae tested. This relationship suggests that the selective pressure of antimicrobial drugs constitutes an important factor to the persistence of $\mathrm{Hg}$ tolerance, considering the restriction of the use of $\mathrm{Hg}$ compounds in hospitals (5).

We also observed that the interaction of certain metal 
tolerant strains with heavy metals may result in alterations on the pigmentation, and that these alterations are not necessarily related to the ability to survive in the presence of the metal. Apart from this fact, we can admit that, in the environment, the production or enhancement of pigment induced by the stress provoked by metals on certain metal tolerant strains may favour their survival by enhancing their resistance to deleterious agents such as UV radiation from sun light.

Even though we did not observe inhibitory effect of metals on catalase expression, oxidase activity was inhibited by $\mathrm{Hg}$ or $\mathrm{Ag}$ in two metal tolerant strains, while $\mathrm{Cr}$ affected the process of denitrification in one strain, inducing different final products from nitrate degradation, depending on the concentration of the metal. Nevertheless, in relation to inhibition of enzymatic activity, the most intense effect observed in our study was, doubtlessly, the loss of the capacity to degrade gelatin in the presence of heavy metals.

Finally, considering the results obtained, we can presume that even in the case of metal tolerant bacteria these elements are able to determine changes in different types of metabolic activities or physiological expressions. This fact has to be taken into account in situations such as in the utilization of metal tolerant microorganisms for bioremediation of contaminated environments and in the evaluation of the impact of metals on metal tolerant microorganisms in relation to the cycling of chemical elements and substrate degradation.

\section{ACKNOWLEDGEMENTS}

This study was supported by FAPERJ (Fundação de Amparo à Pesquisa do Estado do Rio de Janeiro - Support Research Foundation of Rio de Janeiro State).

\section{REFERENCES}

1. Armstrong, G.A. (1994). Eubacteria show their true colors: genetics of carotenoid pigment biosynthesis from microbes to plants. J. Bacteriol. 176 (16), 4795-4802.

2. Basu, M.; Bhattacharya, S.; Paul, A.K. (1997). Isolation and characterization of chromium-resistant bacteria from tannery effluents. Bull. Environ. Contam. Toxicol. 58 (4), 535-542.

3. Bauer, A.W.; Kirby, W.M.M.; Sherris, J.C.; Turck, M. (1996). Antibiotic susceptibility testing by a standardized single disc method. Amer. J. Clin. Pathol. 45, 493-496.

4. Bitton, G.; Freihofer, V. (1978). Influence of extracellular polysaccharides on the toxicity of copper and cadmium towards Klebsiella aerogenes. Microbial Ecol 4: 119-125.

5. Brasil. Resolução RE $n^{\circ}$ 528, de 17 de abril de 2001. Diário Oficial [da] República Federativa do Brasil, Brasília p.147,8 jun. 2001.

6. Castro-Silva; M. A.; Souza Lima, A. O.; Gerchenski, A. V.; Jaques, D. B.; Rodrigues, A. L.; Lima de Souza, P.; Rörig, L. R. (2003). Heavy metal resistance of microorganisms isolated from coal mining environments of Santa Catarina. Braz. J. Microbiol. (34) suppl.1. 45-47.

7. Chopra, I. (2007). The increasing use of silver-based products as antimicrobial agents: a useful development or a cause for concern? $J$. Antimicrob. Chemother. 59, 587-590.

8. Choudhury, P.; Kumar, R. (1998). Multidrug- and metal-resistant strains of Klebsiella pneumoniae isolated from Penaeus monodon of the coastal waters of deltaic Sundarban. Can. J. Microbiol. 44 (2), 186-189.

9. Duxbury, T. (1986). Microbes and heavy metals: an ecological overview. Microbiol. Sci. 3 (11), 330-333.

10. Duxbury, T.; Bicknell, B. (1983). Metal-tolerant bacterial populations from natural and metal-polluted soils. Soil. Biol. Biochem. 15 (3), 243250 .

11. Ferreira da Silva, M.; Vaz-Moreira, I.; Gonzalez-Pajuelo, M.; Nunes, O.C.; Manaia. C.M. (2007). Antimicrobial resistance patterns in Enterobacteriaceae isolated from an urban wastewater treatment plant. FEMS Microbiol. Ecol. 60 (1), 166-176.

12. Foster, T.J. (1983). Plasmid-determined resistance to antimicrobial drugs and toxic metal ions in bacteria. Microbiol. Rev. 47 (3), 361-409.

13. Fugimore, H.; Kiyono, M.; Nobuhara, K.; Pan-Hou, H. (1996). Possible involvement of red pigments in defense against mercury in Pseudomonas K-62. FEMS Microbiol. Lett. 135 (2-3), 317-321.

14. Furman, C.R.; Owusu, V.I.; Tang, J.C. (1984). Inhibitory effect of some transition metal ions on growth and pigment formation of Serratia marcescens. Microbios 40 (159), 45-51.

15. Gadd, G.M. (1992). Metals and microorganisms: A problem of definition. FEMS Microbiol. Lett. 100 (1-3), 197-204.

16. Gayatri, R.; Rajaram, R; Ramasami, T. (2000). Inhibition of collagenase by $\mathrm{Cr}(\mathrm{III})$ : its relevance to stabilization of collagen. Biochim. Biophys Acta. 1524 (2-3), 228-37.

17. Gupta, L.K.; Jindal, R.; Beri, H.K.; Chhibber, S. (1992). Virulence of silver-resistant mutant of Klebsiella pneumoniae in burn wound model. Folia Microbiol. 37 (4), 245-248.

18. Haefeli, C.; Franklin, C.; Hardy, K. (1984). Plasmid-determined silver resistance in Pseudomonas stutzeri isolated from a silver mine. J. 
Bacteriol. 158 (1): 389-392.

19. Hassen, A.; Saidi, N.; Cherif, M.; Boudabous, A. (1998). Effects of heavy metals on Pseudomonas aeruginosa and Bacillus thuringiensis. Bioresourse Technol. 65 (1-2), 73-82.

20. Hughes, M.N.; Poole, R.K. (1989). Metal toxicity. In: Hughes, M.N.; Poole, R.K. (eds). Metals and microorganisms. Chapman and Hall, London, p. 252-301.

21. Hughes, M.N.; Poole, R.K. (1989). The functions of metals in microorganisms. In: Hughes, M.N.; Poole, R.K. (eds). Metals and microorganisms. Chapman and Hall, London, p. 1-38.

22. Joly, B.; Cluzel, R.; Enry, P.H.; Barjot, J. (1976). La résistance de Pseudomonas aux antibiotiques et aux métaux lourds: CMI et transferts. Ann. Microbiol. (Inst. Pasteur) 127 B, 57-68.

23. Kanayama, Y.; Sakai, Y. (2005). Purification and properties of a new type of protease produced by Microbacterium liquefaciens. Biosci. Biotechnol. Biochem. 69 (5); 916-921.

24. Lima e Silva, A.A.; Hofer, E. (1993). Resistance to antibiotics and heavy metals in Escherichia coli from marine fish. Environ. Toxicol. Water. Qual. 8 (1), 1-11.

25. Lima e Silva, A.A.; Pereira, M.P.; Silva Filho, R.G.; Hofer, E. (2007). Utilization of phenol in the presence of heavy metals by metal-tolerant nonfermentative Gram-negative bacteria isolated from wastewater. Rev. Latinoam. Microbiol. 49 (3-4), 68- 73.

26. Lima-Bittencourt, C.I.; Cursino, L.; Gonçalves-Dornelas, H.; Pontes, D.S.; Nardi, R.M.D.; Callisto, M.; Chartone-Souza, E.; Nascimento, A.M.A. (2007). Multiple antimicrobial resistance in Enterobacteriaceae isolates from pristine freshwater. Genet. Mol. Res. 6 (3), 510-521.

27. MacFaddin, J.F. (2000). Biochemical Tests for Identification of Medical Bacteria. Willians and Wilkins, Baltimore.

28. McIntosh, D., Cunningham, M., Ji, B., Fekete, F. A., Parry, E. M., Clark, S. E., Zalinger, Z. B., Gilg, I. C., Danner, G. R., Johnson, K. A., Beattie, M., Ritchie, R. (2008). Transferable, multiple antibiotic and mercury resistance in Atlantic Canadian isolates of Aeromonas salmonicida subsp. salmonicida is associated with carriage of an IncA/C plasmid similar to the Salmonella enterica plasmid pSN254. J. Antimicrob. Chemother. 61 (6): 1221-1228.

29. Mindlin, S.; Kholodii, G.; Gorlenko, Z.; Minakhina, S.; Minakhin, L.; Kalyaeva, E.; Kopteva, A.; Petrova, M.; Yurieva, O.; Nikiforov, V. (2001). Mercury resistance transposons of Gram-negative environmental bacteria and their classification. Res. Microbiol. 152 (9), 811-822.

30. National Committe for Clinical Laboratory Standards (2002). Performance Standards for Antimicrobial Susceptibility Testing. $12^{\text {th }}$ Informational Supplement. NCCLS document M100. Waine, PA, USA.

31. Nwuche, C.O.; Ugoji, E.O. (2008). Effects of heavy metal pollution on the soil microbial activity. Int. J. Environ. Sci. Tech. 5(3), 409-414.

32. Otth, L.; Solís, Gabriela; Wilson, M.; Fernández, H. (2005). Susceptibility of Arcobacter butzleri to heavy metals. Braz. J. Microbiol. 36 (3):286-288.

33. Percival, S.L.; Bowler, P.G.; Russel, D. (2005). Bacterial resistance to silver in wound care. J. Hosp. Infect. 60, 1-7.

34. Pires-Bouças, P. D; Izumi, E.; Furlaneto-Maia, L.; Sturion, L.; Suzart, S. (2010). Effects of environmental and nutritional factors on gelatinolytic activity by Enterococcus faecalis strains isolated from clinical sources. Afr. J. Microbiol. Res. 4 (10), 969-976.

35. Roane, T.M.; Pepper, I.L. (1999). Microbial responses to environmentally toxic cadmium. Microb. Ecol. 38 (4), 358-364.

36. Silver, S.; Misra, T.K. (1988). Plasmid-mediated heavy metal resistances. Annu. Rev. Microbiol. 42, 717-743.

37. Sobolev, D.; Begonia, M.F. (2008). Effects of heavy metal contamination upon soil microbes: lead-induced changes in general and denitrifying microbial communities as evidenced by molecular markers. Int. J. Environ. Res. Public Health. 5 (5), 450-456.

38. Sterrit, R.M.; Lester, J.N. (1980). Interactions of heavy metals with bacteria. Sci. Total Environ. 14, 5-17.

39. Trevors, J.T; Oddie, K.M.; Belliveau, B.H. (1985). Metal resistance in bacteria. FEMS Microbiol. Rev.32 (1): 39-54.

40. Vaituzis, Z.; Nelson, J.D.; Wan, L.W.; Colwell, R.R. (1975). Effects of mercuric chloride on growth and morphology of selected strains of mercury-resistant bacteria. Appl. Microbiol. 29 (2), 275-286.

41. Wireman, J.; Liebert, C.A.; Smith, T.; Summers, A.O. (1997). Association of mercury resistance with antibiotic resistance in the Gramnegative fecal bacteria of primates. Appl. Environ. Microbiol. 63 (11), 4494-4503.

42. Yurieva, O.; Kholodii, G.; Minakhin, L.; Gorlenko, Z.; Kalyaeva, E.; Mindlin, S.; Nikiforov, V. (1997). Intercontinental spread of promiscuous mercury resistance transposons in environmental bacteria. Mol. Microbiol. 24 (2), 321-329. 